\title{
Efektifitas Pendidikan Kesehatan Melalui Group Whasapp Reminder Berkala Dengan Metode Ceramah Terhadap Pemberian Asi Eksklusif Pada Ibu Pasca Seksio Sesarea
}

\author{
Sri Mulyani, Andi Subandi \\ Fakultas Kedokteran dan Ilmu Kesehatan Universitas Jambi \\ Email: yani jogjam@yahoo.co.id
}

\begin{abstract}
ABSTRAK
Persalinan seksio sesarea merupakan kondisi yang mempengaruhi ibu dalam pemberian ASI eksklusif bagi bayinya. Ibu perlu menemukan posisi yang nyaman untuk dapat menyusui. Perut daerah insisi perlu dijaga dengan menggunakan bantal. Pasca operasi caesar, bayi tetap perlu mendapatklan kolostrum, dan ibu belajar menyusui. Pemberian ASI pada periode awal bermanfaat untuk mencegah payudara bengkak dan pasokan ASI selalu terjaga. Tingkat pemahaman ibu terkait pentingnya ASI eksklusif bagi bayinya berpengaruh terhadap perilaku ibu untuk tidak menyusui bayinya. Pemahaman kurang dapat didipengaruhi oleh pendidikan yang kurang, rendahnya pengetahuan, sikap dan informasi yang diterima. Berbagai faktor baik predisposisi, faktor pendukung dan pendoroong sangat diperlukan bagi ibu. Pendidikan kesehatan dapat dilakukan menggunakan berbagai media seperti media audio (verbal), media visual (leaflet, dll), media audio visual (video, televisi), serta media internet. Tujuan penelitian ini untuk mengetahui efektifitas pendidikan kesehatan melalui group whasapp reminder berkala dengan metode ceramah terhadap ASI eksklusif pada ibu pasca seksio sesarea. Rancangan penelitian yang akan digunakan quasi experiment. Hasil penelitian menunjukkan terdapat perbedaan sebelum dan sesudah penerapan metode ceramah pada ibu menyusui dengan Asi Eksklusif atau Asi Tidak Eksklusif dan disimpulkan bahwa terdapat perbedaan sebelum dan sesudah penerapan metode Group Whasapp pada ibu menyusui dengan Asi Eksklusif atau Asi Tidak Eksklusif.
\end{abstract}

\section{Kata Kunci: ASI Eksklusif, Pendidikan Kesehatan, WhatApp, Seksio Sesarea}

\section{PENDAHULUAN}

Angka Kematian Ibu (AKI) yang disebabkan oleh persalinan dengan cara seksio sesarea sekitar 5,8 per 100.000 persalinan, sedangkan angka morbiditas atau kesakitannya mencapai 27,3 per 1.000 persalinan. Angka tersebut cukup besar dibandingkan dengan persalinan normal yaitu 9 per 1.000 persalinan. Persalinan seksio sesarea yang angka mortalitas dan morbiditasnya cukup tinggi dilaksanakan 
dengan beberapa alasan sehingga diputuskan untuk dilakukan, diantaranya karena perdarahan saat usia kehamilan preterm kala II lama, ibu dengan penyakit diabetes melitus, letak janin melintang, tafsiran berat bayi besar, plasenta previa, dan panggul kecil (Depkes RI, 2006).

Bagi ibu dengan proses melahirkan secara sekso sesarea, sering kesulitan untuk segera menyusui bayinya. Hal ini terjadi karena adanya ketidaknyaman diantaranya rahim sering berkontraksi untuk kembali ke bentuk semula atau involusi. Selain itu rasa nyeri pada jahitan luka insisi di abdomen (Ita \& Cinthya, 2009).

Kesulitan menyusui pada ibu pasca melahirkan seksio sesarea juga dapat terjadi karena adanya permasalahan puting susu yang masuk ke dalam, adanya bedah payudara, ibu menderita sakit, ibu sedang mengkonsumsi obat, persalinan dengan bayi kembar, adanya gangguan epidural juga masalah pada tulang belakang. Kesulitan bertambah jika ibu dilakukan bius umum pada saat proses operasi dikarenakan di jam-jam pertama paska melahirkan ibu tidak sadar. Kendala ini juga dapat bertambah jika ibu meminum obat sebelum persalinan yang dapat menyebabkan bayi banyak mengantuk (Mansjoer, 2001).

Faktor lain yang memiliki pengaruh cukup besar untuk menyusui bayi adalah adanya pengaruh lingkungan. Budaya yang dianut juga cukup berpengaruh terhadap ibu untuk memutuskan akan menyusui atau tidak pada bayinya. Pengetahuan, peran pasangan, orang tua, petugas kesehatan, sikap menerima atau tidak kehamilann sangat berpengaruh dalam pengambilan keputusa untuk menyusui atau tidak (Manuaba, 2010).

Tingkat pemahaman ibu terkait pentingnya ASI eksklusif bagi bayinya berpengaruh terhadap perilaku ibu untuk tidak menyusui bayinya. Pemahaman kurang dapat didipengaruhi oleh pendidikan yang kurang, rendahnya pengetahuan, sikap dan informasi yang diterima. Berbagai faktor baik predisposisi, faktor pendukung dan pendoroong sangat diperlukan bagi ibu (Notoadmodjo, 2012).

Persalinan seksio sesarea merupakan kondisi yang mempengaruhi ibu dalam pemberian ASI eksklusif bagi bayinya. Ibu perlu menemukan posisi yang nyaman untuk dapat menyusui. Perut daerah insisi perlu dijaga dengan menggunakan bantal. Pasca operasi caesar, bayi tetap perlu mendapatklan kolostrum, dan ibu belajar menyusui. Pemberian ASI pada periode awal bermanfaat untuk mencegah payudara bengkak dan pasokan ASI selalu terjaga (Ganong, 2008).

Rahma (2012) dalam penelitiannya mendapatkan hasil bahwa dari 35 responden, 27 responden tidak mengetahui bagaimana perawatan post partum sectio caesaria serta tidak mengetahui perilaku ibu menyusui yang baik dan benar. Notoadmodjo (2012) menyatakan bahwa penegtahuan tentang kesehatan akan mempengaruhi perilaku pada jangka menengah dari suatu pendidikan kesehatan, kemudian perilaku kesehatan akan mempengaruhi indikatator kesehatan 
masyarakat yang merupakan dari outcome suatu pendidikan kesehatan. Perilaku yang didasari pengetahuan, sikap yang baik maka perilaku akan langgeng (long lasting), begitu juga sebaliknya (Notoatmodjo, 2012).

Upaya meningkatkan perilaku untuk mencapai kesehatan yang optimal perlu diberikan pendidikan kesehatan sebagai usaha atau kegiatan tersebut (Notoatmodjo,2014). Pendidikan kesehatan dapat dilakukan menggunakan berbagai media seperti media audio (verbal), media visual (leaflet, dll), media audio visual (video, televisi), serta media internet (Ahmad Kholid, 2014). Media internet merupakan media yang sangat efektif dikarenakan mampu mencangkup semua jenis media tanpa adanya keterbatasan ruang dan waktu. Aplikasi berbasis internet bukan hal baru lagi dan saat ini sedang diminati oleh kaum remaja, salah satunya aplikasi yang sedang digemari remaja saat ini adalah WhatsApp Berdasarkan hasil penelitiannya Desain penelitian yang digunakan adalah pre experimental dengan jenis penelitian yang digunakan adalah one-group pre-post test design. Jumlah sampel sebanyak 36 orang yang dipilih dengan teknik kuota sampling. Hasil penelitian menunjukkan terjadinya peningkatan nilai rerata sikap remaja sebelum dan sesudah diberi pendidikan kesahatan melalui WhatsApp Reminder sebesar $8,48 \%$. Hasil uji hipotesis menggunakan uji paired $t$-test dengan nilai $\mathrm{p}$ value $=0,000$ $(\mathrm{p}<0,05)$ berarti ada pengaruh pendidikan kesehatan melalui WhatsApp reminder berkala terhadap sikap remaja mengenai seks pranikah oleh karena itu diharapkan kepala sekolah SMKN 2 Sukawati memberikan pendidikan kesehatan seks pranikah dengan bantuan orang yang ahli dibidangnya secara berkala (Suadnyana, 2019).

Notoadmodjo (2012) mendefinisikan pendidikan kesehatan sebagai semua kegiatan yang digunakan untuk meningkatkan pengetahuan, sikap dan praktek pada indvidu, keluarga dan masyarakat dalam upaya meningkatkan derajat kesehatan mereka. Kemenkes (2015) menyatakan bahwa pendidikan kesehatan bisa menjadi upaya pencegahan primer yang digunakan untuk mencegah faktor resiko. Pemberian pendidikan kesehatan ini dapat melalui berbagai media, yang diharapkan dapat memperluas jangkauan informasi pada masyarakat. Media spanduk, pesan singkat melalui perangkat hand pone, koran, pesawat radio, TV dan jejaring sosial merupakan 6 media yang dapat digunakan swcara efektif untuk edukasi pada masyarakat (Kemenkes, 2015).

Laranjo dkk (2014) dan Korp (2005), berpendapat penggunaan media internet dan media sosial sudah cukup lama berperan dalam meningkatkan derajat kesehatan masyarakat. Secara global orang menggunakan internet untuk mendapatkan informasi tentang kesehatan, terutama kesehatan berkaitan dengan teknik perawatan. Kebiasaan mencari informasi melalui media internet merupakan peluang yang dapat dimanfaatkan oleh tenaga kesehatan dalam memberikan informasi kesehatan dengan lebih mudah dan efektif. Hasil survei yang dilakukan oleh Asosiasi Penyelenggara Jasa Internet Indonesia (APJII) pada tahun 2016 menunjukkan bahwa pengguna media internet di Indonesia sebanyak 132,7 juta 
dengan pengguna berumur 10-24 tahun yang berjumlah cukup banyak yaitu 24,4 juta..

Data Statista (2018), sebanyak 49\% penduduk Indonesia adalah pengguna media sosial dengan $40 \%$ penduduknya sebagai pengguna aktif aplikasi Whatsapp Messenger. Data statista juga menunjukkan bahwa $40 \%$ pengguna Whatsapp Messenger di Indonesia menggunakan whatsApp untuk group chat. Ekadinata dan Doni (2017) menyatakan bahwa program edukasi dengan memanfaatkan media pengiriman pesan teks dan gambar tentang DM tipe 2 dalam aplikasi whatsapp terbukti efektif untuk meningkatkan pengetahuan tentang DM tipe 2 pada kader posbindu dari skor rata-rata 16,15 meningkat menjadi 22,78.

\section{METODE PENELITIAN}

\section{Rancangan Penelitian}

Penelitian ini merupakan penelitian quasi experiment yang menggunakan static group comparison. Merupakan kegiatan percobaan yang bertujuan untuk mengetahui suatu gejala atau pengaruh yang timbul, sebagai akibat dari adanya perlakuan tertentu. Percobaan itu berupa perlakuan atau intervensi terhadap suatu variabel, dari perlakuan tersebut diharapkan terjadi perubahan atau pengaruh terhadap variabel yang lain. Pada penelitian ini terdapat dua kelompok, kelompok eksperimen dan kelompok kontrol/pembanding. Kelompok eksperimen akan mendapat perlakuan $(X)$ yang diikuti dengan pengukuran atau observasi (02). Hasil observasi ini kemudian dibandingkan dengan hasil observasi pada kelompok kontrol yang tidak mendapat perlakuan. Rancangan ini dapat diilustrasikan sebagai berikut:

\section{Kelompok Whatapp \\ Kelompok Ceramah}

$$
\text { Perlakuan Post-test }
$$

Keterangan:

$X$ : perlakuan dengan pijat oketani

02: hasil post-test

\section{Populasi Penelitian}

Populasi penelitian ibu post seksio sesarea di wilayah kerja puskesmas Kota Jambi.

\section{Sampel Penelitian}

Pengambilan sampel dilakukan pada periode waktu tertentu, sampai dengan jumlah sampel terpenuhi. Jumlah sampel yang diambil adalah: 


$$
\begin{aligned}
& \mathrm{n}=\frac{2 \sigma^{2}\left(\mathrm{Z}_{1-\alpha / 2}+\mathrm{Z}_{1-\beta}\right)^{2}}{\left(\mu_{1-}-\mu_{2}\right)^{2}} \\
& \mathrm{n}=\mathrm{n} 2=\frac{2(4)(1,96+0,842)^{2}}{(11-9)^{2}}=\frac{62,809}{4}=16 \text { orang }
\end{aligned}
$$

Sampel yang diambil sesuai dengan kriteria inklusi. Berdasarkan penghitungan dengan rumus di atas maka jumlahnya adalah 16 responden.

Kriteria inklusi subyek pada penelitian ini adalah:

1. Ibu pasca seksio sesarea yang tidak ada kontraindikasi untuk menyusui dengan bayi sehat dan tidak ada kontraindikasi untuk menyusu

2. Bersedia menjadi responden

\section{HASIL DAN PEMBAHASAN}

\section{Karakteristik Responden Berdasar Umur}

Tabel 1. Distribusi Frekuensi Responden Berdasarkan Kelompok Umur di RSIA Annisa

\begin{tabular}{cccccc}
\hline \multirow{2}{*}{ No } & Usia & \multicolumn{2}{c}{ Metode Ceramah } & \multicolumn{2}{c}{ Metode Whasapp } \\
\cline { 3 - 6 } & $\begin{array}{c}\text { Frekuensi } \\
(\mathrm{f})\end{array}$ & $\begin{array}{c}\text { Presentase } \\
(\%)\end{array}$ & $\begin{array}{c}\text { Frekuensi } \\
(\mathrm{f})\end{array}$ & $\begin{array}{c}\text { Presentase } \\
(\%)\end{array}$ \\
\hline 1 & $<20$ Tahun & 0 & 0 & 0 & 0 \\
\hline 2 & $\begin{array}{c}20- \\
\text { 35Tahun }\end{array}$ & 11 & 68,75 & 10 & 62,5 \\
\hline 3 & $>35$ Tahun & 5 & 31,25 & 6 & 37,5 \\
\hline & Total & 16 & 100 & 16 & 100 \\
\hline
\end{tabular}

Berdasarkan tabel diatas, diperoleh gambaran karakteristik respondem menunjukkan bahwa sebagian besar 11 (68,75\%) dengan kelompok umur 21-35 tahun pada kelompok metode ceramah

\section{Karakteristik Responden Berdasarkan Pendidikan}

Tabel 2. Distribusi Frekuensi Responden Berdasarkan Pendidikan di RSIA Annisa

\begin{tabular}{cccccc}
\hline & & \multicolumn{2}{c}{ Metode Ceramah } & \multicolumn{2}{c}{ Metode Whasapp } \\
\cline { 3 - 6 } No & Pendidikan & $\begin{array}{c}\text { Frekuensi } \\
(\mathrm{f})\end{array}$ & $\begin{array}{c}\text { Presentase } \\
(\%)\end{array}$ & $\begin{array}{c}\text { Frekuensi } \\
(\mathrm{f})\end{array}$ & $\begin{array}{c}\text { Presentase } \\
(\%)\end{array}$ \\
\hline 1 & SMP & 2 & 12,5 & 1 & 6,25 \\
\hline 2 & SMA & 9 & 56,25 & 10 & 62,5 \\
\hline 3 & PT & 5 & 31,25 & 5 & 31,25 \\
\hline & Total & 16 & 100 & 16 & 100 \\
\hline
\end{tabular}


Berdasarkan tabel diatas, diperoleh gambaran karakteristik responden menunjukkan sebagian besar 10 (62,5\%) dengan pendidikan SMA pada kelompok metode whasapp

\section{Karakteristik Responden Berdasarkan Pekerjaan}

Tabel 3. Distribusi Frekuensi Responden Berdasarkan Pekerjaan di RSIA Annisa

\begin{tabular}{cccccc}
\hline \multirow{2}{*}{ No } & Pekerjaan & \multicolumn{2}{c}{ Metode Ceramah } & \multicolumn{2}{c}{ Metode Whasapp } \\
\cline { 3 - 6 } & $\begin{array}{c}\text { Frekuensi } \\
(\mathrm{f})\end{array}$ & $\begin{array}{c}\text { Presentase } \\
(\%)\end{array}$ & $\begin{array}{c}\text { Frekuensi } \\
(\mathrm{f})\end{array}$ & $\begin{array}{c}\text { Presentase } \\
(\%)\end{array}$ \\
\hline 1 & IRT & 12 & 92,3 & 9 & 56,25 \\
\hline 2 & Swasta & 3 & 18,75 & 3 & 18,75 \\
\hline 3 & ASN & 1 & 6,25 & 1 & 6,25 \\
\hline 4 & Wiraswasta & 0 & 0 & 0 & 0 \\
\hline & Total & 16 & 100 & 16 & 100 \\
\hline
\end{tabular}

Berdasarkan tabel diatas diperoleh gambaran karakteristik responden menunjukkan bahwa sebagian besar 12 (92,3\%) sebagai ibu rumah tangga pada kelompok metode ceramah

\section{Karakteristik Responden Berdasarkan Gravida}

Tabel 4. Distribusi Frekuensi Responden Berdasarkan Gravida di RSIA Annisa

\begin{tabular}{cccccc}
\hline \multirow{2}{*}{ No } & $\begin{array}{c}\text { Status } \\
\text { Persalinan }\end{array}$ & $\begin{array}{c}\text { Metode Ceramah } \\
\text { Frekuensi } \\
(\mathrm{f})\end{array}$ & $\begin{array}{c}\text { Presentase } \\
(\%)\end{array}$ & $\begin{array}{c}\text { Frekuensi } \\
(\mathrm{f})\end{array}$ & $\begin{array}{c}\text { Presentase } \\
(\%)\end{array}$ \\
\hline 1 & Multipara & 16 & 100 & 16 & 100 \\
\hline 2 & $\begin{array}{c}\text { Grande } \\
\text { Multipara }\end{array}$ & 0 & 0 & 0 & 0 \\
\hline & Total & 16 & 100 & 16 & 100 \\
\hline
\end{tabular}

Berdasarkan table diatas, diperoleh gambaran karakteristik responden menunjukkan bahwa sebagian besar $16(100 \%)$ dengan status persalinan multipara pada kelompok metode ceramah dan metode washapp. 


\section{Karakteristik Responden Berdasarkan Perilaku Menyusui Anak Sebelumnya}

Tabel 5. Distribusi Frekuensi Responden Berdasarkan Perilaku Menyusui Sebelumnya di RSIA Annisa

\begin{tabular}{cccccc}
\hline \multirow{2}{*}{ No } & $\begin{array}{c}\text { Status } \\
\text { Menyusui }\end{array}$ & $\begin{array}{c}\text { Metode Ceramah } \\
\text { Frekuensi } \\
(\mathrm{f})\end{array}$ & $\begin{array}{c}\text { Presentase } \\
(\%)\end{array}$ & $\begin{array}{c}\text { Frekuensi } \\
(\mathrm{f})\end{array}$ & $\begin{array}{c}\text { Presentase } \\
(\%)\end{array}$ \\
\hline 1 & $\begin{array}{c}\text { ASI } \\
\text { Eksklusif }\end{array}$ & 2 & 12,5 & 1 & 6,25 \\
\hline 2 & $\begin{array}{c}\text { Tidak ASI } \\
\text { Eksklusif }\end{array}$ & 14 & 87,5 & 15 & 93,75 \\
\hline & Total & 16 & 100 & 16 & 100 \\
\hline
\end{tabular}

Berdasarkan table diatas, diperoleh gambaran karakteristik responden menunjukkan bahwa sebagian besar 15 (93,75\%) dengan status menyusui anak sebelumnya ASI tidak eksklusif pada kelompok metode ceramah dan metode washapp.

\section{Karakteristik Responden Berdasarkan Perilaku Menyusui Anak Setelah Intervensi}

Tabel 6 Distribusi Frekuensi Responden Berdasarkan Perilaku Menyusui Anak setelah Intervensi di RSIA Annisa

\begin{tabular}{cccccc}
\hline \multirow{2}{*}{ No } & $\begin{array}{c}\text { Status } \\
\text { Menyusui }\end{array}$ & $\begin{array}{c}\text { Metode Ceramah } \\
\text { Frekuensi } \\
(\mathrm{f})\end{array}$ & $\begin{array}{c}\text { Presentase } \\
(\%)\end{array}$ & $\begin{array}{c}\text { Frekuensi } \\
(\mathrm{f})\end{array}$ & $\begin{array}{c}\text { Presentase } \\
(\%)\end{array}$ \\
\hline 1 & $\begin{array}{c}\text { ASI } \\
\text { Eksklusif }\end{array}$ & 14 & 87,5 & 13 & 81,25 \\
\hline 2 & $\begin{array}{c}\text { Tidak ASI } \\
\text { Eksklusif }\end{array}$ & 2 & 12,5 & 3 & 18,75 \\
\hline & Total & 16 & 100 & 16 & 100 \\
\hline
\end{tabular}

Berdasarkan tabel diatas, diperoleh gambaran karakteristik responden menunjukkan bahwa sebagian besar $14(87,5 \%)$ dengan status menyusui anak sekarang ASI eksklusif pada kelompok metode ceramah 


\section{Uji Wilcoxon terhadap Menyusui pada Ibu Post Seksio Sesarea Sebelum dan Sesudah dilakukan Metode Ceramah}

Tabel Uji 7 Wilcoxon terhadap Menyusui pada Ibu Post Seksio Sesarea Sebelu dan Sesudah dilakukan Metode Ceramah

Rank

\begin{tabular}{llr|r|r}
\hline & & $\mathrm{N}$ & \multicolumn{1}{c}{$\begin{array}{c}\text { Mean } \\
\text { Rank }\end{array}$} & $\begin{array}{c}\text { Sum of } \\
\text { Ranks }\end{array}$ \\
\hline $\begin{array}{l}\text { Menyusui Anak } \\
\text { saat ini - Menyusui } \\
\text { Anak Sebelumnya }\end{array}$ & $\begin{array}{l}\text { Negative } \\
\text { Ranks }\end{array}$ & $0^{\mathrm{a}}$ & .00 & .00 \\
\cline { 2 - 5 } & $\begin{array}{l}\text { Positive } \\
\text { Ranks }\end{array}$ & $12^{\mathrm{b}}$ & 6.50 & 78.00 \\
\cline { 2 - 5 } & Ties & $4^{\mathrm{c}}$ & & \\
\cline { 2 - 5 } & Total & 16 & & \\
\hline
\end{tabular}

a. Menyusui Anak saat ini < Menyusui Anak Sebelumnya

b. Menyusui Anak saat ini > Menyusui Anak Sebelumnya

c. Menyusui Anak saat ini = Menyusui Anak Sebelumnya

Berdasarkan uji Wilcoxon, diperoleh pada tabel "Ranks" untuk 'Negative Ranks' antara Menyusui Anak Saat Ini dan Menyusui Anak Sebelumnya adalah 0 untuk N, yang berarti tidak terdapat ibu menyusui yang berpindah dari Asi Eksklusif ke Asi Tidak Eksklusif. Kemudian Mean Ranks sebesar 0.00 yang berarti rata-rata perubahan tersebut ialah sebesar 0.00 . Terakhir, jumlah ranks sebesar 0.00 berarti bahwa jumlah ranking negatif sebesar 0.00 .

Pada 'Positive Ranks' antara Menyusui Anak Saat Ini dan Menyusui Anak Sebelumnya, diperoleh nilai 12 untuk N, yang berarti terdapat 12 ibu menyusui yang berpindah dari Asi Tidak Eksklusif ke Asi Eksklusif. Mean Ranks diperoleh sebesar 6.50 yang berarti rata-rata perubahannya sebesar 6.50. Kemudian Sum of Ranks sejumlah 78.00 yang berarti jumlah ranking positif sejumlah 78.00.

Terakhir pada nilai 'Ties' antara Menyusui Anak Saat Ini dan Menyusui Anak Sebelumnya, diperoleh nilai 4 untuk N, yang berarti terdapat 4 ibu menyusui yang tidak berpindah dari Asi Tidak Eksklusif ke Asi Eksklusif maupun sebaliknya. 
Tabel 8 Test Statistik Metode Ceramah

\begin{tabular}{l|r}
\hline & \multicolumn{2}{c}{ Test Statistics $^{\mathrm{a}}$} \\
\hline & \multicolumn{2}{c}{$\begin{array}{c}\text { Menyusui Anak saat ini - } \\
\text { Sebelumnya }\end{array}$} \\
\hline $\mathrm{Z}$ & \multicolumn{2}{c}{} \\
\hline Asymp. Sig. (2-tailed) & .001 \\
\hline a. Wilcoxon Signed Ranks Test & \\
\hline b. Based on negative ranks. & \\
\hline
\end{tabular}

Berdasarkan Output 'Test Statistics' diperoleh nilai Asymp.Sig. (2-tailed) sebesar 0.01 atau kurang dari 0.05 yang berarti tolak nul hipotesis. Hal tersebut berarti dapat dinyatakan bahwa terdapat perbedaan antara Menyusui Anak Saat Ini dan Menyusui Anak Sebelumnya berdasarkan metode ceramah. Jadi, dapat disimpulkan bahwa terdapat perbedaan sebelum dan sesudah penerapan metode ceramah pada ibu menyusui dengan Asi Eksklusif atau Asi Tidak Eksklusif.

\section{Uji Wilcoxon Rank terhadap Menyusui pada Ibu Post Seksio Sesarea Sebelum dan Sesudah dilakukan Metode Whatapp}

\begin{tabular}{llr|r|r} 
& & \multicolumn{1}{c|}{$\begin{array}{c}\text { Mean } \\
\text { Rank }\end{array}$} & \multicolumn{1}{c}{$\begin{array}{c}\text { Sum of } \\
\text { Ranks }\end{array}$} \\
\hline $\begin{array}{l}\text { Menyusui Anak } \\
\text { saat ini - Menyusui }\end{array}$ & $\begin{array}{l}\text { Negative } \\
\text { Anak Sebelumnya }\end{array}$ & $0^{\mathrm{a}}$ & .00 & .00 \\
& $\begin{array}{l}\text { Positive } \\
\text { Ranks }\end{array}$ & $12^{\mathrm{b}}$ & 6.50 & 78.00 \\
& Ties & $4^{\mathrm{c}}$ & & \\
\cline { 2 - 5 } & Total & 16 & & \\
\hline
\end{tabular}

a. Menyusui Anak saat ini < Menyusui Anak Sebelumnya

b. Menyusui Anak saat ini > Menyusui Anak Sebelumnya

c. Menyusui Anak saat ini = Menyusui Anak Sebelumnya

Berdasarkan uji Wilcoxon, diperoleh pada tabel "Ranks" untuk 'Negative Ranks' antara Menyusui Anak Saat Ini dan Menyusui Anak Sebelumnya adalah 0 untuk N, yang berarti tidak terdapat ibu menyusui yang berpindah dari Asi Eksklusif ke Asi Tidak Eksklusif. Kemudian Mean Ranks sebesar 0.00 yang berarti rata-rata perubahan tersebut ialah sebesar 0.00 . Terakhir, jumlah ranks sebesar 0.00 berarti bahwa jumlah ranking negatif sebesar 0.00 .

Pada 'Positive Ranks' antara Menyusui Anak Saat Ini dan Menyusui Anak Sebelumnya, diperoleh nilai 12 untuk $\mathrm{N}$, yang berarti terdapat 12 ibu menyusui 
yang berpindah dari Asi Tidak Eksklusif ke Asi Eksklusif. Mean Ranks diperoleh sebesar 6.50 yang berarti rata-rata perubahannya sebesar 6.50. Kemudian Sum of Ranks sejumlah 78.00 yang berarti jumlah ranking positif sejumlah 78.00.

Terakhir pada nilai 'Ties' antara Menyusui Anak Saat Ini dan Menyusui Anak Sebelumnya, diperoleh nilai 4 untuk N, yang berarti terdapat 4 ibu menyusui yang tidak berpindah dari Asi Tidak Eksklusif ke Asi Eksklusif maupun sebaliknya.

\begin{tabular}{lr}
\multicolumn{2}{c}{ Test Statistics $^{\text {a }}$} \\
\hline \multicolumn{3}{c}{$\begin{array}{c}\text { Menyusui Anak saat ini - } \\
\text { Menyusui Anak } \\
\end{array}$} & $\begin{array}{c}\text { Sebelumnya } \\
\text { Z }\end{array}$ \\
\hline Asymp. Sig. (2-tailed) & $-3.464^{\mathrm{b}}$ \\
\hline a. Wilcoxon Signed Ranks Test & .001 \\
\hline b. Based on negative ranks. & \\
\hline
\end{tabular}

Berdasarkan Output 'Test Statistics' diperoleh nilai Asymp.Sig. (2-tailed) sebesar 0.01 atau kurang dari 0.05 yang berarti tolak nul hipotesis. Hal tersebut berarti dapat dinyatakan bahwa terdapat perbedaan antara Menyusui Anak Saat Ini dan Menyusui Anak Sebelumnya berdasarkan metode Group Whatsapp. Jadi, dapat disimpulkan bahwa terdapat perbedaan sebelum dan sesudah penerapan metode Group Whasapp pada ibu menyusui dengan Asi Eksklusif atau Asi Tidak Eksklusif.

\section{PEMBAHASAN}

Pendidikan pada klien telah lama menjadi sytandar pada praktik keperawatan professional. Perawat memiliki peran untuk meningkatkan tingkat pemahaman klien dan demikian meningkatkan kesehatan. Untuk menjadi seorang pendidik yang efektif, perawat harus melakukan lebih dari sekedar memberikan informasi saja. Perawat harus menentukan secara hati-hati apa yang klien perlu ketahui dan menentukan waktu yang tepat kapan klien siap belajar. Durasi sesi pengajaran mempengaruhi kemampuan belajar. Sesi yang diperpanjang akanmenurunkan perhatian dan konsentrasi. Umumnya sebuah sesi yang berlangsung selama 20 menit akan lebih mudah ditoleransi dan menarik minat klien atas materi yang diberikan. Perawat dapat menggunakan berbagai variasi untuk menampilkan isi pengajaran. Semua panca indra adalah saluran untuk menyampaikan informasi (Potter \& Perry, 2005).

Metode ceramah merupakan pendekatan pendidikan yang dapat secara signifikan meningkatkan pengetahuan siswa pada tujuan tertentu dengan cara penyajian materi pembelajaran melalui penuturan secara lisan (Bany, et all, 2014). Penelitian Sari, dkk (2019) diketahui bahwa penyuluhan dengan metode ceramah 
kurang efektif dalam meningkatkan kesadran makan remaja, meningkatkan intense remaja underweight, tidak efektif untuk meningkatkan pola tidur remaja.

Berdasarkan hasil penelitian Dinengsih dan Hakim (2020) tentang pengaruh metode ceramah dan metode aplikasi berbasis android terhadap pengetahuan kesehatan reproduksi remaja, didapatkan hasil bahwa terdapat pengaruh pemberian ceramah tentang kesehatan reproduksi remaja terhadap peningkatan pengetahan kesehatan reproduksi remaja dengan $p$ value 0,000. Dari hasil penelitian tersebut diketahui bahwa terdapat engaruh pemberian aplikasi android terhadap peningkatan pengetahuan remaja tentang kesehatan reproduksi dengan nilai $p$ value 0,000 .

Penelitian Rahmawati dan Elsanti. (2020). Diketahui bahwa metode ceramah efektif terhadap tingkat pengetahuan remaja tentang kesehatan reproduksi sebelum dan sesudah dilakukan pendidikan kesehatan dengan nilai $p$ value $=0.000$. Metode ceramah efektif terhadap sikap remaja tentang kesehatan reproduksi sebelum dan sesudah dilakukan pendidikan kesehatan. Berdasarkan hasil penelitian yang telah dilakukan, diketahui juga bahwa metode ceramah efektif terhadap sikap remaja tentang kesehatan reproduksi dengan nilai $p$ value $=0,000$. Dengan adanya intervensi berupa penyuluhan ternyata dapat mempengaruhi peningkatan sikap seseorang terhadap suatu hal. Sikap remaja tentang kesehatan reproduksi dipengaruhi oleh pengetahuan remaja yang sama, serta ada kemungkinan juga sikap sudah ada terbentuk karena faktor sosial budaya di lingkungan tempat tinggal. Berdasarkan hasil uji hasil selisih rata-rata pre test -post test metode ceramah dan small group discussion terhadap pengetahuan dan sikap remaja diketahui metode small group discussion lebih efektif dalam meningkatkan pengetahuan dan sikap responden.

Pemberian pendidikan kesehatan merupakan satu kesatuan kegiatan yang tidak dapat dipisahkan untuk menangani masalah kesehatan yang berkaitan dengan pola perilaku masyarakat. Perilaku seseorang didasari oleh pengetahuan dan sikap sehingga untuk merubah perilaku seseorang harus diawali dari pengetahuan, selain itu pengetahuan merupakan faktor predisposisi dari determinan perilaku (Notoatmodjo, 2010).

Berdasarkan penelitian Nengsih dkk (2019) diketahui bahwa terdapat perbedaan antara pengetahuan ibu sebelum diberikan penyuluhan dan sesudah diberikan penyuluhan dengan nilai p-value 0.000 , sehingga disimpulkan adanya efektifitas penyuluhan kesehatan dengan metode ceramah, leaflet, dan juga pemaparan power point terhadap peningkatan pengetahuan tentang pembuatan MP-ASI pada ibu yang memiliki bayi/balita di posyandu RW 001 Desa mampir Puskesmas Gandoang Cileungsi-Bogor Tahun 2019.

Berdasarkan hasil penelitian Rahayuningsih \& Arofah (2019) diketahui bahwa metode numbered head together lebih efektif untuk meningkatkan pengetahuan ibu hamil tentang ASI eksklusif dinbandingkan dengan metode ceramah. Pada penelitian menunjukkan adanya perbedaan yang signifikan antara 
metode numbered head together dan metode ceramah. Metode numbered head together memiliki rerata dan peningkatan lebih tinggi dibandingkan dengan metode ceramah. Metode ceramah hanya membuat responden terpaku pada penjelasan pemateri dan responden kurang aktif.

Penelitian Vizeshafar, dkk (2019) diketahui bahwa terdapat perbedaan nilai pengetahuan yang signifikan antara dua kelompok yang dilakukan role play dan metode ceramah dengan nilai $\mathrm{p}$ value 0,001 , dan metode role play lebih efektif dibandingkan dengan metode ceramah, karena dalam role play lebih dapat meningkatkan kerjasama dan penampilan diskusi antar pemain perannya.

Hasil penelitian Salsabila dkk (2018) ini didapatkan pengetahuan baik pada kelompok perlakuan $91,2 \%$ dan niat $73,5 \%$ sedangkan pada kelompok kontrol baik hanya $17,6 \%$ dan niat $14,7 \%$. Tes Hasil penelitian menunjukkan p-value $(0,0001)<0,05$ pada pengetahuan dan niat memiliki p-value $(0,0001)<0,05$ sehingga dapat disimpulkan bahwa terdapat perbedaan yang signifikan antara pengetahuan dan niat ibu setelah diberikan intervensi dengan booklet. media dengan metode ceramah interaktif tentang ASI eksklusif. Media booklet dengan metode ceramah mempengaruhi pengetahauan ibu tentang ASI eksklusif di wilayah kerja puskesmas Sungai Ulin (p-value $=0,0001$ ), pengetahuan baik meningkat $67,6 \%$. Metode ceramah dengan booklet mempengaruhi niat ibu untuk memberikan ASI eksklusif ( $p$-value $=0,0001$ ), niat berubah menjadi lebih kuat $50 \%$. Hasil penelitian menunjukkan $p$-value $(0,0001)<0,05$ pada pengetahuan dan niat memiliki $p$-value $(0,0001)<0,05$ sehingga disimpulkan bahwa terdapat perbedaan pengetahuan dan niat pada kelompok control dan eksperimen setelah diberikan intervensi adalah pvalue 0,0001

Berdasarkan penelitian Sari (2019) diketahui bahwa perbedaan rata-rata pengetahuan, sikap, dan persepsi responden yang menggunakan teknologi di grup WhatsApp lebih tinggi daripada perbedaan di rata-rata pengetahuan, sikap, dan persepsi responden dengan meggunakan teknologi di Grup Instagram. Berdasarkan hasil analisis uji mann-whitney diperoleh nilai p 0,00 ( $\mathrm{p}<0,05)$, diketahui terdapat perbedaan yang signifikan pengetahuan, sikap, dan persepsi responden yang menggunakan teknologi Promosi Kesehatan BSE antara promosi kesehatan menggunakan WhatsApp dan Instagram. Media WhatsApp dikenal sebagai media yang lebih efektif daripada Instagram.

Berdasarkan Penelitian Utami (2020) analisis statistik menunjukkan bahwa nilai $p=0,00(p \leq 0,05)$ sehingga dapat dinyatakan bahwa ada perbedaan peningkatan sikap Ayah ASI terhadap dukungannya dalam pemberian ASI eksklusif yang signifikan sebelum dan sesudah diberikan pendidikan kesehatan melalui penggunaan media WhatsApp. Analisis statistic juga menunjukkan bahwa nilai $\mathrm{p}=0,619(\mathrm{p} \geq 0,05)$ sehingga dinyatakan tidak terdapat perbedaan peningkatan sikap yang bermakana antara kelompok yang menggunakan media WhatsApp dan kelompok yang menggunakan media Booklet. Berdasarkan analisis statistik tidak terdapat perbedaan peningkatan efektifitas yang bermakna $(p=0,619 \geq 0,005)$ antara 
penggunaan media WhatsApp dan Booklet. Namun pada masing -masing kelompok pretest dan posttest terlihat bahwa kelompok yang diberikan pendidikan kesehatan dengan menggunakan media WhatsApp memiliki peningkatan rata rata skor sikap yang lebih besar dibandingkan Booklet. Nilai mean peningkatan sikap kelompok yang diberikan pendidikan kesehatan menggunakan media WhatsApp sebesar 9,20, sedangkan kelompok yang diberikan pendidikan kesehatan menggunakan media Booklet sebesar 8,73.

Berdasarkan hasil analisis dari penelitian Aminuddin dan Bong (2018) didapatkan bahwa ibu-ibu post partum yang telah mendapatkan brosur/leaflet tentang ASI ekslusif lebih baik tingkat pemahamannya dibandingkan dengan ibuibu post partum yang mendapatkan ceramah. Dengan uji t- test diperoleh nilai $t$ hitung $(2,251)>$ nilai $\mathrm{t}$ tabel $(2,048)$ pada $\mathrm{df}=28$ dan $\alpha=0,05$ yang berarti menunjukkan ada perbedaan yang bermakna antara metode ceramah dan metode brosus/leaflet dengan tingkat pemahaman ibu post partum tentang ASI ekslusif.

Penelitian lapangan (field reasrch) yang dilakukan Daheri dkk (2020) didapatkan bahwa penggunaan WhatsApp sebagai media pembelajaran daring kurang efektif dalam mencapai tujuan pembelajaran. Hal ini disebabkan berbagai faktor, diantaranya kurangnya penjelasan yang komprehensif dan sederhana dari guru, rendahnya aspek afektif dan psikomotorik pada pembelajaran, sinyal internet, kesibukan orang tua dan latar belakang pendidikan orang tua. Ketika peneliti menelisik efektifitas penggunaan WhatsApp sebagai media pembelajaran mayoritas orang tua menyimpulkan tidak efektif yakni 41,2\%. 33,3 persen meragukan efektifitas WhatsApp ini. Hanya 25,5\% yang meyakini efektifitasnya.

Hasil penelitian Sukriani dan Arisani (2020) menunjukkan rata-rata usia responden adalah 26,94 tahun. Sebagian besar responden adalah ibu rumah tangga atau tidak bekerja $(63,9 \%)$, berpendidikan tinggi dan menengah $(88,9 \%)$ dan memiliki pendapatan keluarga yang tinggi $(77,7 \%)$. Berdasarkan hasil uji statistik, Grup WhatsApp efektif digunakan untuk meningkatkan kualitas ASI perilaku ibu pada minggu pertama setelah melahirkan $(p<0,05)$.

Berdasarkan hasil uji statistik pada penelitian Ermitha dan Yuniarti (2020) menggunakan Wilcoxon Signed Rank dapat diketahui bahwa rerata pengetahuan ibu menyusui sebelum diberikan pendidikan kesehatan dengan media whatsapp adalah 45,40 dengan nilai terendah pada saat pretest 33 dan nilai tertinggi pretest adalah 93, sedangkan rerata pengetahuan ibu menyusui setelah diberikan pendidikan kesehatan dengan media whatsapp adalah 87,87 dengan nilai terendah pada saat pretest 73 dan nilai tertinggi postest adalah 100 didapatkan nilai $\mathrm{p}=0.000$. Dapat disimpulkan bahwa ada perbedaan peningkatan pengetahuann sebelum dan sesudah diberikan pendidikan kesehatan melalui media whatsapp.

Hasil penelitian Utami, Fahri (2020) menunjukkan ada peningkatan rerata pada pengetahuan Ibu yang diberikan edukasi ASI melalui media video $(p=0,0001)$ dan media teks $(p=0,0001)$. Tidak ada peningkatan rerata pada sikap ibu yang 
diberikan edukasi ASI melalui media video $(\mathrm{p}=0,317)$, namun ada peningkatan rerata pada sikap Ibu yang diberikan edukasi ASI melalui media teks $(p=0,008)$.

Berdasarkan penelitian kualitatif Darmalaksana (2020) didapatkan hasil bahwa WhatsApp terbukti efektif di beberapa tempat untuk kuliah mobile. Efektifitas itu dapat dirasakan dalam beberapa peristiwa kuliah non tatap muka di Jurusan Ilmu Hadis Fakultas Ushuluddin UIN Sunan Gunung Djati Bandung. Penelitian ini merekomendasikan agar dilakukan evaluasi yang memadai terhadap pemanfaat aplikasi WhatsApp

\section{KESIMPULAN}

Berdasarkan Output 'Test Statistics' diperoleh nilai Asymp.Sig. (2-tailed) sebesar 0.01 atau kurang dari 0.05 yang berarti tolak nul hipotesis. Hal tersebut berarti dapat dinyatakan bahwa terdapat perbedaan antara Menyusui Anak Saat Ini dan Menyusui Anak Sebelumnya berdasarkan metode ceramah. Jadi, dapat disimpulkan bahwa terdapat perbedaan sebelum dan sesudah penerapan metode ceramah pada ibu menyusui dengan Asi Eksklusif atau Asi Tidak Eksklusif.

Dan berdasarkan Output 'Test Statistics' diperoleh nilai Asymp.Sig. (2-tailed) sebesar 0.01 atau kurang dari 0.05 yang berarti tolak nul hipotesis. Hal tersebut berarti dapat dinyatakan bahwa terdapat perbedaan antara Menyusui Anak Saat Ini dan Menyusui Anak Sebelumnya berdasarkan metode Group Whatsapp. Jadi, dapat disimpulkan bahwa terdapat perbedaan sebelum dan sesudah penerapan metode Group Whasapp pada ibu menyusui dengan Asi Eksklusif atau Asi Tidak Eksklusif.

\section{DAFTAR PUSTAKA}

Aminuddin M., Bong F.S., Efektifitas metode ceramah dan metode leaflet/brosur terhadap tingkat pemahaman ibu-ibu post partum tentang ASI eksklusif. Jurnal Kesehatan Pasak Bumi Kalimantan. JKPKB Vol. 1. No. 2 Desember 2018

Bany Z.U., Sunnati, Darman W. Perbandingan Efektifitas Penyuluhan Metode Ceramah dan Demonstrasi terhadap Pengetahuan Kesehatan Gigi dan Mulut Siswa SD. Journal Cakradonya Dent J 2014; 6(1):619-677

Chapman, 2006. Asuhan Kebidanan : Persalinan \& Kelahiran. Penerbit EGC. Jakarta. Cuningham, et.al, 2009. Obstetri Williams-Panduan Ringkas. Penerbit EGC, Jakarta Cendikia, 2010. Panduan Pintar Hamil dan Melahirkan. Penerbit PT. Wahyu Medika, Jakarta

Daheri M., Juliana, Deriwanyo, Amda A.D. 2020. Efektifitas whastapp sebagai media belajar daring. JUrnal Basicedu Volume 4 Nomor 4 Tahun 2020. 775783. https://jbasic.org/index.php/basicedu/index

Darmalaksana W. 2020. Whatsapp kuliah mobile. Fakultas Ushuluddin UIN Sunan Gunung Djati bandung 27 Maret 2020 
Depkes RI, 2006. Program Pembangunan Kesehatan. Depkes RI, Jakarta

Dinengsih S., Hakim N. 2020. Pengaruh metode ceramah dan metode aplikasi android terhadap pengetahuan kesehatan reproduksi remaja. Jurnal Kebidanan Vol 6. No.4 Oktober 2020: 515-522

Ermitha Y., Yuniarti. 2020. Pengaruh pendidikan kesehatan melalui media leaflet dan whasapp terhadap peningkatan pengetahuan pemberian ASI eksklusif. Mahakam Midwifery Journal, Vol 5. No. 1, Mei 2020: 12-26

Juditha Ita \& Ida Cintihya, S. 2009. Tips Praktis Bagi Wanita Hamil. Penerbit Forum Kita. Jakarta.

Ganong, W.F. 2008. Buku Ajar Fisiologi Kedokteran. Jakarta : EGC.

Hubertin, 2003. Konsep Penerapan ASI Eksklusif. Buku Saku Untuk Bidan. Jakarta : EGC

Kriebs, 2010. "Buku Saku Asuhan Kebidanan Varney". Jakarta, Buku Kedokteran EGC.

Mansjoer, Arif. 2001. Kapita Selekta Kedokteran. Penerbit Medika Aesculapius FKUI, Jakarta.

Manuaba, I.B.G, 2010. Ilmu Kebidanan, Penyakit Kandungan dan Keluarga Berencana Untuk Pendidikan Bidan, Penerbit EGC. Jakarta.

Mitayani, 2009. Asuhan Keperawatan Maternitas. Penerbit Salemba Medika, Jakarta

Mochtar, R. 2008. Sinopsis Obstetri. Penerbit EGC, Jakarta.

Morison, J, M. 2004. Seri Pedoman Praktis Manajemen Luka. Penerbit EGC, Jakarta.

Notoatmodjo, 2007. Ilmu Kesehatan Masyarakat, Ilmu dan Seni. Penerbit Rineka Cipta, Jakarta.

Nengsih,Y., Kubillawati s., Daulay NA. 2019. Pengaruh penyuluhan terhadap pengetahuan ibu dalam membuat MP-ASI di Posyandu RW 001 Desa Mampir Puskesmas Gandoang-Cileungsi Tahun 2019. Jurnal Ilmiah Kesehatan \& Kebidanan Vol. IX No.2 Juni 2020 ISSN: 2252-9675 E-ISSN: 2722-368X

Notoatmodjo, S. (2010). Ilmu Perilaku Kesehatan. Jakarta: Rineka Cipta

Notoatmodjo, 2012. Promosi Kesehatan E Perilaku Kesehatan. Rineka Cipta, Jakarta.

Nugroho, dkk. (2014). Buku Ajar Asuhan Kebidanan Nifas. Yogyakarta : Nuha Medika.

Potter \& Perry. 2005. Buku Ajar Fundamental Keperawatan: Konsep, Proses, dan Praktik Edisi 4. Jalarta: EGC

Rahmawati K., Elsanti D. 2020. Efektifitas Metode Ceramah dan Small Group Discussion tenang kesehatan reproduksi terhadap tingkat pengetahuan dan sikap remaja SMA Muhammadiyah Sokaraja. Jurnal keperawatan Muhammadiyah. September

2020. https://journal.um.surabaya.ac.id/index.php/JKM

Rahayuningsih F.B., Arofah, R.N. 2019. Pendidikan kesehatan dengan metode numbered head together dan metode ceramah tentang ASI eksklusif sebagai upaya peningkatan pengetahuan ibu hamil di kecamatan kartasura. Prosiding seminar nasional mewujudkan masyarakat madani dan lestari seri 9 
"pemukiman cerdas dan tanggap bencara" Yogyakarta 24 Oktober 2019. ISBN: 978-602-6215-79-6

Rahma, 2012. Hubungan Pengetahuan, Persepsi dan Motivasi Ibu Post Partum Sectio Caesaria Tentang Pemberian ASI di RSU dr. Sutomo Semarang. http://www.digital.library.co.id. Diakses tanggal 29 November 2014

Roesli, 2010. Mengenal ASI Eksklusif. Jakarta : Trubus Agriwidya.

Salsabila N., Suhartono E., Arifin S., Husaini, Roselina., Panghiyangani. 2018. The effect of booklet media with interavctive lecture interactive method on mother's knowledge and intention in giving exclusive breastfeeding in the sungai ulin public health center working area. International Journal of Research Publications. 2018. www.ijrp.org

Sari, E, zahtamal, Nurlisis, Novita rany, Septiani. 2019. Efektifitas Media Bergambar dan Penyuluhan Metode Ceramah Tanya Jawab (CTJ) terhadap perilaku makan, aktifitas fisik dan Pola Tidur Remaja underweight Tahun 2019. Altamimi Kesmas jurnal Ilmu Kesehatan Masyarakat. Volume 8, Nomor 2, tahun 2019. P-ISSN: 2338-2147. http://jurnal.alinsyirah.ac.id/index.php/kesmas

Sari A.F. 2019. The effectiviness of whatsapp and instagram as breast self examination (BSE) Health promotion media to prevent breast cancer. The international Conference ASEAN 2019 page 258-265 DOI: https://doi.org/10.1515/9783110678666-034

Suadnyana, I (2019) Pengaruh Pendidikan Kesehatan melalui Whatsapp Reminder Berkala terhadap Sikap Remaja Mengenai Seks Pra nikah. Denpasar

Sukriani W., Arisani G., Effecttiveness of whatsapp group on breastfeeding practices. Indian Journal of Forensic \& Taxicology, October-December 2020, Vol 14 No. 4

Suherni, Hesty Widyasih, dan Anita Rahmawati. 2009. Perawatan Masa Nifas.Yogyakarta : Fitramaya

Utami R.U., Sari U S., Sopianingsih J. 2020. Efektifitas penggunaan media melalui whatapp dan booklet terhadap sikap ayah ASI di Wilayah kerja puskesmas Tuan-tuan kecamatan benua kayong kabupaten ketapang. Jurnal Kebidanan Khatulistiwa Volume 6 Nomor 2, Juli 2020, hlm 83-90 P-ISSN 2460-1853, EISSN 2715-727X

Utami, Fahri A.D., 2020. Pengaruh edukasi melalui media video dan teks pada group whashapp terhadap pengetahuan dan sikap ibu tentang ASI di Kota Medan. Repository Institusi USU. 2020.http://repositori.usu.ac.id/handle/12345678/28858

Vizeshfar F., Zare M., Keshtkaran Z. 2019. Role-play versus lecture methods in community health volunteer. Vol 79. Agustus 2019. Page 175-179. https://doi.org/10.10/j.nedt.2019.05.028

Widyasari, 2011. Perilaku Ibu Post Caesarea di RSU Mitra Sejati, Medan.

Winkjosastro, H, et.al, 2005. Ilmu Kebidanan. Penerbit Yayasan Bina Pustaka Sarwono Prawirohardjo (YBPSP), Jakarta. 
Wiwit, 2010. Gambaran Pengetahuan, Persepsi dan Sikap Ibu Post Sectio Caesaria Terhadap Inisiasi Menyusui Dini (IMD) di RSU dr. Wahyudin Semarang, http:www.digital.library.co.id. diakses tanggal 25 November 2014

Yeyeh, AR. 2010. "Asuhan Kebidanan IV (Patologi Kebidanan)". Jakarta : TIM 2010. CV. Trans Info Media. 